\title{
MIND MAPPING MATA PELAJARAN MATEMATIKA UNTUK KELAS IX SEMESTER GANJIL
}

\author{
Ni Luh Emi Dayani ${ }^{*}$, Nurhayati Abbas $^{2}$, Yamin Ismail ${ }^{3}$ \\ 1,2,3 Jurusan Matematika, Universitas Negeri Gorontalo, Bone Bolango 96119, Indonesia \\ *Penulis Korespondensi.Email: emi.dayani31@gmail.com
}

\begin{abstract}
Abstrak
Penelitian ini menggunakan pendekatan deskrptif kualitatif, dan Jenis penelitiannyan adalah penelitian studi pustaka (library research). Penelitian ini bertujuan untuk menampilkan sub-sub materi melalui mind mapping matematika untuk kelas IX semester ganjil, dengan berusaha mengumpulkan data dengan cara membaca, menelaah memahami dan menganalisa buku maupun jurnal-jurnal penelitian, mengakses situs-situs internet, maupun dari dokumen yang berkaitan dengan mind mapping. Mind mapping adalah cara paling efektif dan efisien untuk memasukan, menyimpan dan mengeluarkan data dari otak atau ke dalam otak. Sistem ini bekerja sesuai kerja alami otak kita, sehingga dapat mengoptimalkan seluruh potensi dan kapasitas otak manusia. Dalam pembuatan mind mapping, ada beberapa karakteristik pokok yang harus dipenuhi. Adapun karakteristik pokok yang dimaksud yaitu; kertas, warna, garis, huruf, keyword (kata kunci), key image (gambar), dan struktur. Sehingga dapat disimpulkan Mind mapping ini di buat berdasarkan langkah-langkah pembuatan mind mapping, sehingga di hasilkan sebuah mind mapping yang dapat membantu guru dan siswa dalam proses pembelajaran matematika selama semester ganjil, serta dapat membuat pembelajaran lebih bermakna dan menyenangkan karena materi pembelajaran dapat terlihat secara keseluruhan sehingga siswa mudah memahami materi yang di berikan.
\end{abstract}

Kata Kunci: Mind Mapping, Matematika

\begin{abstract}
The study s a qualitative descriptive approach, and his research type is the study of library studies. Researchers aim to project sub-sub materials through the mathematical mind mapping of major semester ix classes, researchers are trying to collect data by reading, studying understanding and analyzing books as well as research journals, accessing Internet sites, or documents related to mind mapping. Mind mapping is the most effective and efficient way to input, store and extract data from the brain or into the brain. It works according to the natural workings of our brain, thus optimizing all the human brain's potential and capacity. The manufacturing of the mind mapping process requires that a number of basic characteristics are attained. There is also the basic characteristic; Paper, colour, line, letter, keyword, key image, and structure. Thus basically the mind mapping process is based on the development of the mind mapping process, resulting in a mind mapping that can help teachers and students in the mathematical process during the difficult part of the semester, and can make learning more meaningful and enjoyable because the learning material is visible to the whole so that students can readily understand the material given.
\end{abstract}

Keywords: Mind Mapping; Mathematics

\section{Pendahuluan}

Pendidikan merupakan suatu usaha yang dilakukan dalam rangka mengembangkan sumber daya manusia yang berkualitas, sebagai bekal untuk menghadapi tantangan perkembangan zaman yang semakin pesat. Namun dalam proses belajar mengajar terdapat beberapa masalah yang dapat menghambat perkembangan siswa diantaranya: Guru mendapat kesulitan menerapkan metode 
pembelajaran yang tepat dan bervariasi. Guru mendapat kesulitan dalam menentukan dan mengidentifikasi materi esensial dan materi sulit. Guru masih mengandalkan Lembaran Kegiatan Peserta didik (LKS) yang dijual penerbit untuk pekerjaan rumah peserta didik karena kesulitan dalam mengembangkan LKS sendiri. Padahal seharusnya LKS yang dikerjakan peserta didik disesuaikan dengan kondisi peserta didik pada sekolah yang bersangkutan. Isi kurikulum yang padat menyulitkan guru untuk mencapai target yang hendak dicapai dan menerapkan pendidikan pada peserta didik sehingga menghambat kemampuan peserta didik berpikir tingkat tinggi [1]. Dari uraian tersebut dapat diketahui bahwa dalampendidikan masih terdapat beragai maslaah pembelajaran sebab penerapan metode pengajaran yang kurang tepat, faktor tingkat kecerdasan siswa yang berbeda, faktor guru yang masih kesuliatan dalam mengidentifikasi materi yang terlalu rumit sehingga menjadi kendala saat hendak memaparkan materi tersebut kepada siswa. Oleh sebab itu dalam hal ini sangat di butuhkan sebuah metode yang tepat sehingga dapat memberikan kemudahan bagi guru untuk menyampaikan materi dengan terstruktur dan mudah dimengerti serta dapat membantu peserta didik dalam mengembangakn pemahaman mereka terhadap materi yang disampaikan dalampembelajaran.

Banyaknya masalah pendidikan matematika di Indonesia merupakan salah satu alasan untuk mereformasi pendidikan matematika di sekolah. Masalah umum dalam pendidikan matematika antara lain: rendahnya daya saing di ajang internasional, rendahnya rata-rata nilai UAN (Ujian Akhir Nasional) bila dibanding dengan pelajaran lain, rendahnya minat belajar matematika disebabkan asumsi anak terhadap pelajaran matematika terasa sulit, apalagi dengan metode pengajaran guru yang kurang menarik yaitu guru menerangkan sementara murid mencatat. Permasalahan lain dalam pembelajaran matematika sebagai berikut: dalam pembelajaran matematika sering terlihat siswa kurang aktif dalam mengikuti pembelajaran, keberanian siswa untuk bertanya kepada guru sangat rendah, apabila ditanya oleh guru tidak ada yang mau menjawab, jika tidak ditunjuk [2]. Terlepas dari masalah pembelajaran di sekolah secara umum, terdapat permasalahan yang cukup serius dalam pembelajaran matematika salah satunya faktor kurangnya minat akan pelajaran matematika ini dikarenakan dianggap pelajaran yang sulit, oleh sebab itu tidak mengherankan bila peserta didik baik dari jenjang sekolah dasar hingga menengah atas banyak yang mengalami kesulitan dalam mempelajari pelajaran matematika ini terlebih lagi dengan kurangnya minat siswa terhadap pelajaran ini guru pengajar masih memiliki kekurangan dalam hal penyampaian materi agar dapat lebih mudah dimengerti siswa sehingga hal tersebut menjadi pemicu kuat rendahnya tingkat penguasaan siswa akan pelajaranmatematika, dengan demikian guru harus mampu meningkatkan kualitas ajarnya dengan terus meningkatkan kreativitas agar dapat menyajikan materi dengan ringkas dan mudah dipahami.

Mind mapping merupakan cara paling efektif dan efisien untuk memasukan, menyimpan dan mengeluarkan data ke dalam otak. Sistem ini bekerja sesuai kerja alami otak manusia, sehingga dapat meningkatkan seluruh kemampuan dan kapasitas otak manusia. Mind mapping adalah cara mencatat yang mudah, menarik, serta menyenangkan dengan menggunakan keseluruhan kemampuan otak melalui perpaduan warna, garis, simbol, dan gambar berwarna-warni sehingga pembelajaran akan lebih diingat dan bermakna. Menurut Carolin Edward, mendefinisikan mind mapping merupakan cara efektif dan efisien untuk mengelola data dari atau ke otak. Dengan menggunakan mind mapping kita dapat mengoptimalkan seluruh kemapuan otak kita dengan maksimal [4]. DePorter dan Mike, berpendapat bahwa Mind mapping memanfaatkan seluruh fungsional otak dengan memaksimalkan penggunaan citra visual dan grafis lainnya untuk meenciptakan keselarasan antara otak kanan dan otak kiri yang terlibat dalam proses masuknya informasi ke otak [5]. Aryana menjelaskan mind mapping merupakan bentuk penulisan catatan penuh warna dan bersifat visual yang dapat dikerjakan oleh satu orang atau satu tim. Dipusatnya terdapat gagasan utama atau gambar sentral. Gagasan utama tersebut mengeksplorasi melalui bagian-bagian yang berasal dari pokok utama yang terhubung langsung dengan gagasan inti itu. Pada setiap bagian pokok inti terdapat bagian terhubung yang disebut sub-gagasan yang menjabarkan setiap pikiran utama lebih dalam lagi. Setiap sub-gagasan lainnya dapat ditambahkan lebih banyak sub-pikiran, mengeksplorasi gagasan utama mendalam lagi, sebagaimana pada bagian lainyapun demikian. Dengan faktor ini memberikan mind map ruang lingkup yang luas yang tidak dimiliki gagasan biasa [6]. 
Menurut Tri Wulandari dalam penelitiannya yang berjudul "Penerapan Metode Pembelajaran Mind Mapping untuk Meningkatkan Preatasi Belajar Matematika Peserta Didik Kelas V MI Baiturrohman Suwaloh Pakel Tulongagung Tahun Ajaran 2015/2016" mengemukakan hasil yang menyatakan bahwa dengan menerapakan mind mapping ini dalam kegiatan belajar siswa dapat meningkatkan prestasi peserta didik mata pelajaran matematika pokok bahasan bangun ruang, dengan demikian dapat diketahui bahwa penggunaan mind mapping dalam sebuah pembelajaran efektif. guru dapat menjadi tambahan referensi mengenai metode pembelajaran yang dapat dipakai meningkatkan hasil belajar pada mata pelajaran matematika yang membuat peserta didik nyaman dan tidak cepat bosan. Peserta didik dapat membantu dalam memahami materi pembelajaran dengan lebih efektif, menyenangkan, dan mudah dipahami serta dapat meningkatkan hasil belajar menjadi lebih baik [7]. Fuaddah Hanum Mahmudah "Penerapan Model Pembelajaran Mind Mapping untuk Meningkatkan Penalaran dan Kreativitas Peserta Didik" menunjukan bahwa penggunaan model pembelajaran mind mapping dapat meningkatkan penalaran dan kreativitas peserta didik [8]. Dalam penelitian yang dilakukan oleh Eka Nur Fitriana dan Mega Teguh Budiarto dengan judul "Efektivitas metode Pembelajaran Mind Mapping pada Pembelajaran Matematika" menunjukan pengelolahan pembelajaran oleh guru memperoleh nulai 4 (sangt baik), aktivitas siswa memperoleh rata-rata $80,00 \%$ (aktif), hasil belajar siswa menunjukan $87,88 \%$ siswa tuntas (lebih dari $75 \%$ tuntas secara klasikal), dan respon siswa termasuk dalam kategori kuat mencapai 57,14\% dan kategori sangat kuat mencapai 42,86\%(positif). Dengan demikian dapat disimpulkan bahwa metode mind mapping dalam pembelajaran matematikasangat efektif [9]. Dalam penelitian yang dilakukan oleh Erma Monariska dengan judul "Penerapan Metode Mind Mapping untuk Meningkatkan Kemampuan Pemahaman Konsep Matematis Mahasiswa Pada Mata Kuliah Kalkulus I" diketahui bahwa peningkatan kemampuan pemahaman konsep matematis mahasiswa menggunkan mind mapping lebih baik daripada mahasiswa yang menggunakan pembelajaran konvensional dilihat dari kemampun awal matematis (rendah, sedang, dan tinggi) serta mahasiswa memiliki sikap positif terhadap penggunaaan metode mind mapping [10]. Dari keempat kajian diatas dapat disimpulkan bahwa mind mapping sangat berpengaruh pada peningkatan kualitas belajar siswa dan sangat membantu siswa dalam mengembangkan potensi belajarnya dikarenakan setiap materi yang di sajikan menjadi lebih mudah dan menarik.

Implementasi yang berbeda dalam penelitian ini adalah memiliki tujuan untuk menjabarkahan bahwa mind mapping juga sangat efektif digunakan dalam pelajaran matematika sebab dalam pelajaran ini sangat banyak hal dan juga kendala yang dalami oleh peserta didik. Dengan tingkatan kecerdasan perserta didik yang berbeda akan sangat berpengaruh dalam hal pemahaman siswa terhadap pelajaran yang di paparkan dengan demikian diperlukan sebuah metode yang mampu menolong siswa agar lebih cepat memahami pelajaran dengan sebuah cara yang simple dan menyenangkan serta bermakna, dengan menggunakan mind mapping pada pelajaran matematika ini tidak hanya mempermudah siswa dalam menangkap isi materi pelajaran namun juga menolong guru agar lebih mudah menyusun materi secara sistematik sehingga proses pembelajaran dapat berjalan dengan baik dan menyenangkan.

\section{Metode Penelitian}

Pendekatan yang digunakan dalam penelitian ini adalah pendekatan kualitatif. Penelitian kualitatif tidak menggunakan uji statistik, tetapi penelitiannya melalui pengumpulan data yang selanjutnya dianalisis dan hasilnya diinterpretasikan [11]. Penelitian kualitatif adalah jenis penelitian yang temuan-temuannya tidak diperoleh melalui prosedur kuantifikasi, perhitungan statistik, atau bentuk cara-cara lainnya yang menggunakan ukuran angka. Penelitian ini prinsipnya untuk memahami objek yang diteliti secara mendalam [12].

Penelitian ini merupakan jenis penelitian studi pustaka (library research). Studi pustaka adalah metode penelitian deskriptif kualitatif yaitu jenis penelitian yang temuan-temuannya tidak di peroleh melalui prosedur statistik atau hitungan angka [13]. Metode kualitatif dapat digunakan untuk menangkap dan memahami sesuatu dibalik fenomena yang belum diketahui dan serta digunakan untuk menambah wawasan. Peneliti berusaha mengumpulkan data dengan cara membaca, menelaah 
memahami dan menganalisa buku atau tulisan baik dari majalah, mengakses situs-situs internet, maupun dari dokumen yang berkaitan dengan mind mapping.

Data dan sumber data dalam penelitian ini adalah data sekunder secara dokumenter atau dokumentasi berupa sejumlah literatur yang relevan dengan judul ini, baik dari buku maupun jurnaljurnal penelitian sebelumnya yang didapat dari internet maupun sumber-sumber pustaka lainya.

Teknik pengumpulan data yang digunakan yaitu teknik pengumpulan secara documenter. Dokumen merupakan catatan peristiwa yang sudah berlalu. Dokumen bisa berbentuk tulisan, gambar, atau karya-karya monumental dari seseorang. Dokumen yang digunakan dalam penelitian ini yaitu dokumen dalam bentuk tulisan berdasarkan teori dan hasil tulisan penelitian seseorang [14].

Teknik analisis data yang digunakan dalam penelitian ini yaitu deskriptif analitis untuk menyusun dan mendeskripsikan data informasi yang didapat mengenai hasil tulisan pakar dari penelitian yang sudah dilakukan sebelumnya.

\section{Hasil dan Pembahasan}

\subsection{Hasil}

Berdasarkan langkah-langkah pembuatan mind mapping, hasil mind mapping mata pelajaran matematika kelas IX semester ganjil yang telah dirancang dan dibuat diuraikan sebagai berikut.

\subsubsection{Hasil Mind Mapping Materi Perpangkatan dan Bentuk Akar}

Mind Mapping Materi Perpangkatan dan Bentuk Akar disajikan secara lengkap pada Gambar 1.

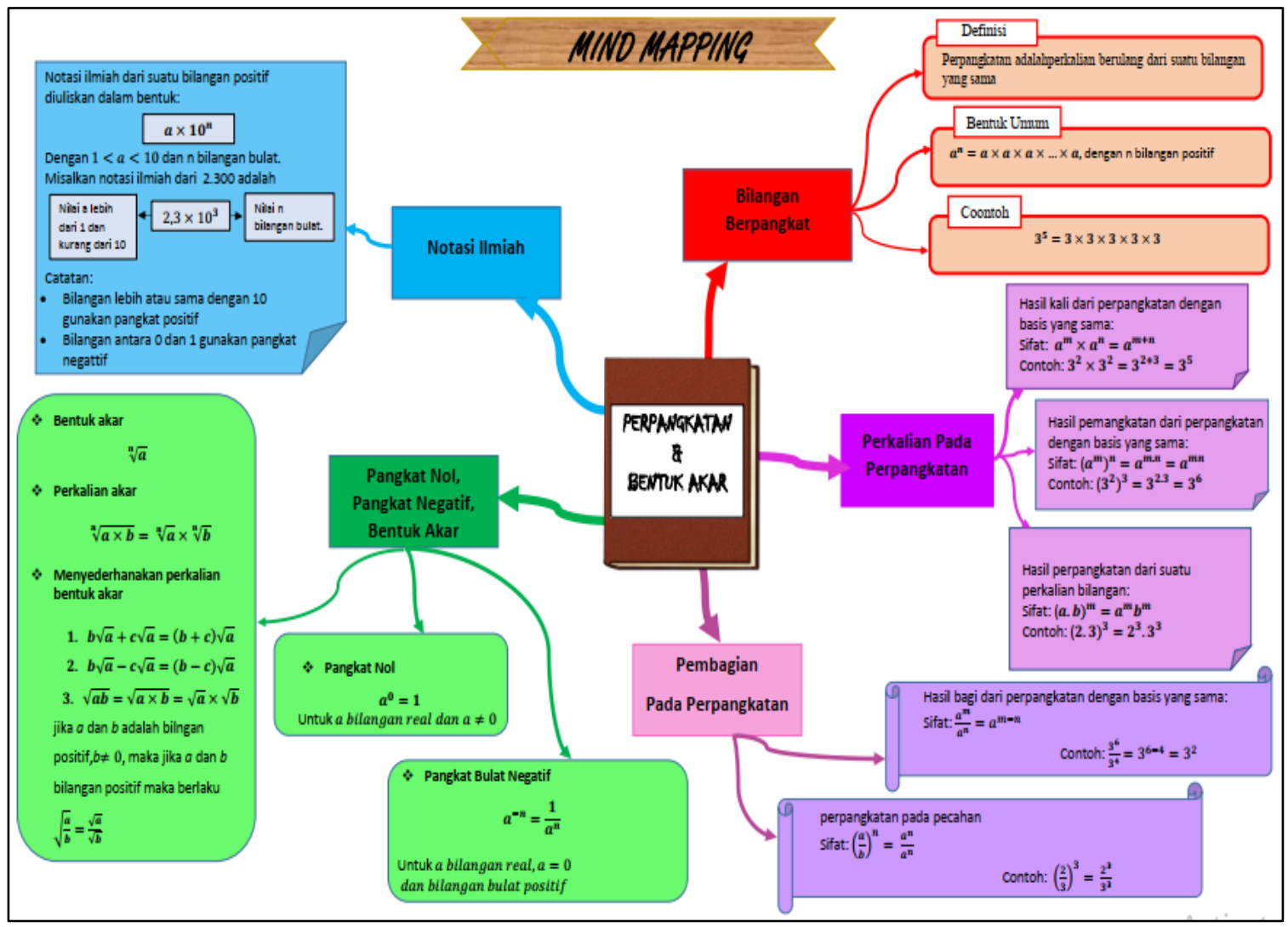

Gambar 1. Hasil Mind Mapping Materi Perpangkatan dan Bentuk Akar

Gambar 1 menampilkan hasil penerapan mind mapping dalam menjabarkan secara ringkas materi perpangkatan dan bentuk akar yang telah di susun dan dirangkai sesuai dengan langkahlangkah pembuatan mind mapp. Tidak hanya menjadikan setiap poin materi lebih mudah di pahami namun juga menjadi semakin menarik dan mampu meningkatkan antusias dan fokus anak dalam belajar. Dalam pembuatannya pun perlu diperhatikan tiap pemilihan warna dan model yang akan 
dipakai, pemilihan kata dan huruf haruslah tepat sehingga tampilan hasil mind mapp yang dibuat terlihat rapi dan lebih mudah untuk dipahami. Dengan demikian penggunaan mind mapp ini menjadi efektif bila dapat diterapkan secara rutin dengan terus meningkatkan kreatifitas dalam pembuatanya sehingga tidak hanya peserta didik menjadi semakin mudah mengerti namun juga guru akan menjadi lebih efisien saat mengajar dikarenakan tiap poin inti materi telah tersusun secara rinci dan rapi yang menjadikan tiap penyampaian materi menjadi semakin mudah ditangkap dan dimengerti peserta didik. Selain efektif dalam membantu proses belajar siswa, dengan mind mapping ini guru menjadi lebih mudah dalam mempersiapkan materi ajar dengan lebih jelas sehing materi ajar disajikan dengan lebih ringkas, memberikan sajian materi yang mudah dipahami sehingga membangkitkan minat belajar anak merupakan sebuah faktor penting yang harus di perhatikan sering kali guru ketika menyampaikan materi ajar selalu menggunakan metode ajar yang sama sehingga membuat peserta didik lebih cepat mengalami rasa jenuh dan menyebabkan daya tangkap anak menurun hal ini lah yang menyebabkan peserta didik menjadi tidak aktif dalam proses belajar mengajar.

\subsubsection{Hasil Mind Mapping Materi Persamaan dan Fungsi Kuadrat}

Mind Mapping Materi Persamaan dan Fungsi Kuadrat disajikan secara lengkap pada Gambar 2.

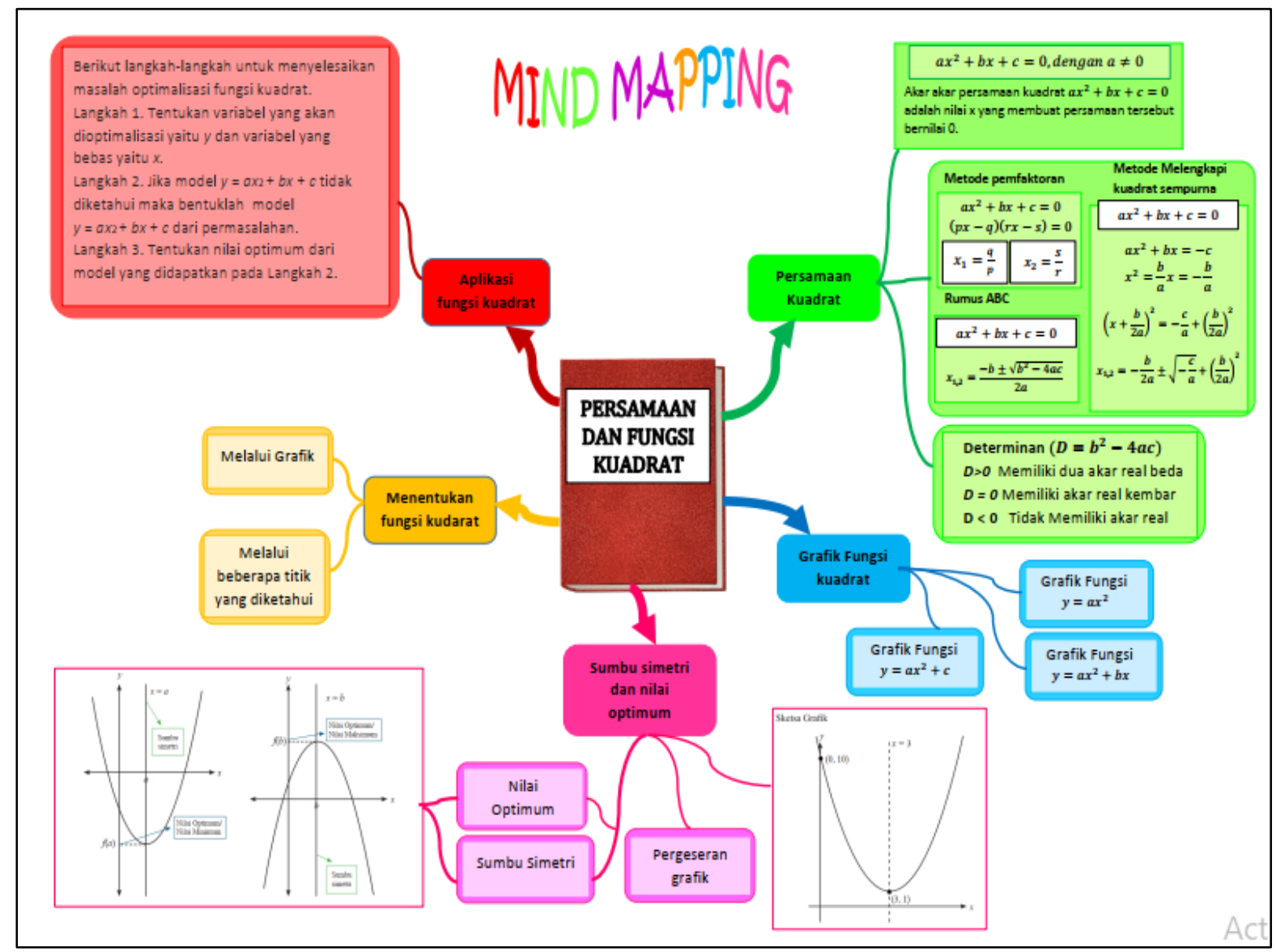

Gambar 2. Hasil Mind Mapping Materi Persamaan Fungsi dan Kuadrat

Gambar 2 menampilkan skema dari mind mapping persamaan dan fungsi kuadrat. Dalam membuat mind mapping sangat penting untuk memikirkan model rangakain yang akan di buat, agar lebih menarik dan bahkan pemilahan warna sangat penting untuk diperhatikan sehinga dapat dengan mudah di ingat tiap poin berbeda dari materi yang diajarkan, seperti halnya pada gambar hasil sebelumnya pada setiap poin inti memiliki warna yang berbeda hal ini bertujuan agar tiap pokok materi yang disajikan dapat dengan mudah diingat sebab selain di sajikan dengan pola dan warna yang berbeda namun memiliki tata letak yang disusun dengan rapi sehingga menambah kemudahan 
peserta didik menangkap dan mengingat setiap materi tersebut.Pada materi persamaan dan fungsi kuadrat ini dapat dilihat bahwa hasil mind mapping dari materi ini disajikan secara sistematik dengan penguraian isi materi yang ringkas namun jelas membuat pokok materi dari pelajaran tersebut mudah dipahami peserta didik serta rumus setiap pokok materinya di letakan pada posisi yang tepat dan menarik sehingga peserta didik dapat dengan tanggap menangkap isi materi yang di jelaskan tersebut dengan optimal.

\subsubsection{Hasil Mind Mapping Materi Transformasi}

Mind Mapping Materi Transformasi disajikan secara lengkap pada Gambar 3.

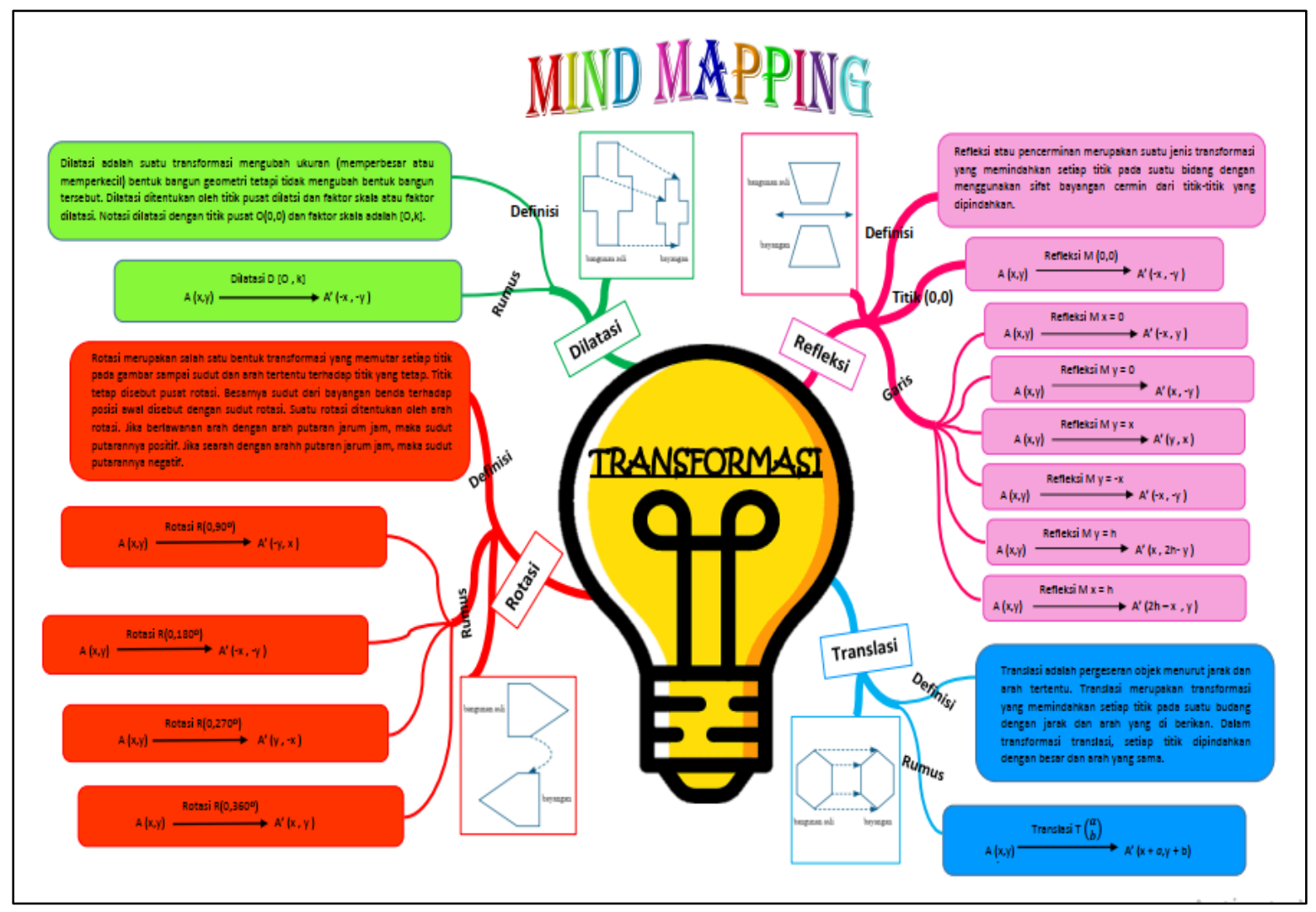

Gambar 3. Hasil Mind Mapping Materi Transformasi

Gambar 3 menampilkan mind mapping dari materi transfomasi. Dimana dalan pembuatnnya diperlukan sebuah kreativitas agar pengunaan mind mapping ini tidak akan menumbulkan perasaan bosan pada peserta didik, oleh karena itu dengan menggunakan mind mapping untuk mempermudah dalam penyampaian materi ini pun perlu dikembangkan dengan berbagai model yang berbeda sehingga antusias anak dalam belajar terus meningkat. Sebab mind mapping bukan hanya merupakan alat bantu untuk mengajar namun juga sebagai alat bantu untuk meningkatkan kreatifitas guru dalam memaksimalkan berbagai metode dan sarana-prasarana dengan maksimal sehingga secara tidak langsung menjadi sebuah pijakan dalam meningkatkan kualitas ajar di sekolah. Menggunakan mind mapping merupakan sebuah solusi yang tepat untuk mengatasi kejenuhan peserta didik dalam belajar, hal ini dikarenakan peserta didik memiliki antusia tinggi terhadap mrtode belajar yang kreatif, sebab pada dasarnya anak lebih tertarik terhadap hal-hal yang menyenangkan yang mampu dianggap meningkatkan motivasi belajarnya disekolah. Dengan demikian dari hasil pembuatan mind mapping dengan dasar materi Transformasi ini disajikan dalam pola dan susunan letak yang berbeda namun masih tetap pada kondisi yang rapi dan jelas. Dalam hal ini terlihat peningkatan sebuah kreatifitas dalam pembuatan mind mapping tidak hanya Nampak pada tampilan tata letak dari tiap pokok materi namun juga pada pemilihan warna yang digunakan dalam pembuatan mind mapping. 


\subsubsection{Hasil Mind Mapping Materi Kekongruenan dan Kesebangunan}

Mind Mapping Materi Kekongruenan dan Kesebangunan disajikan secara lengkap pada Gambar 4.

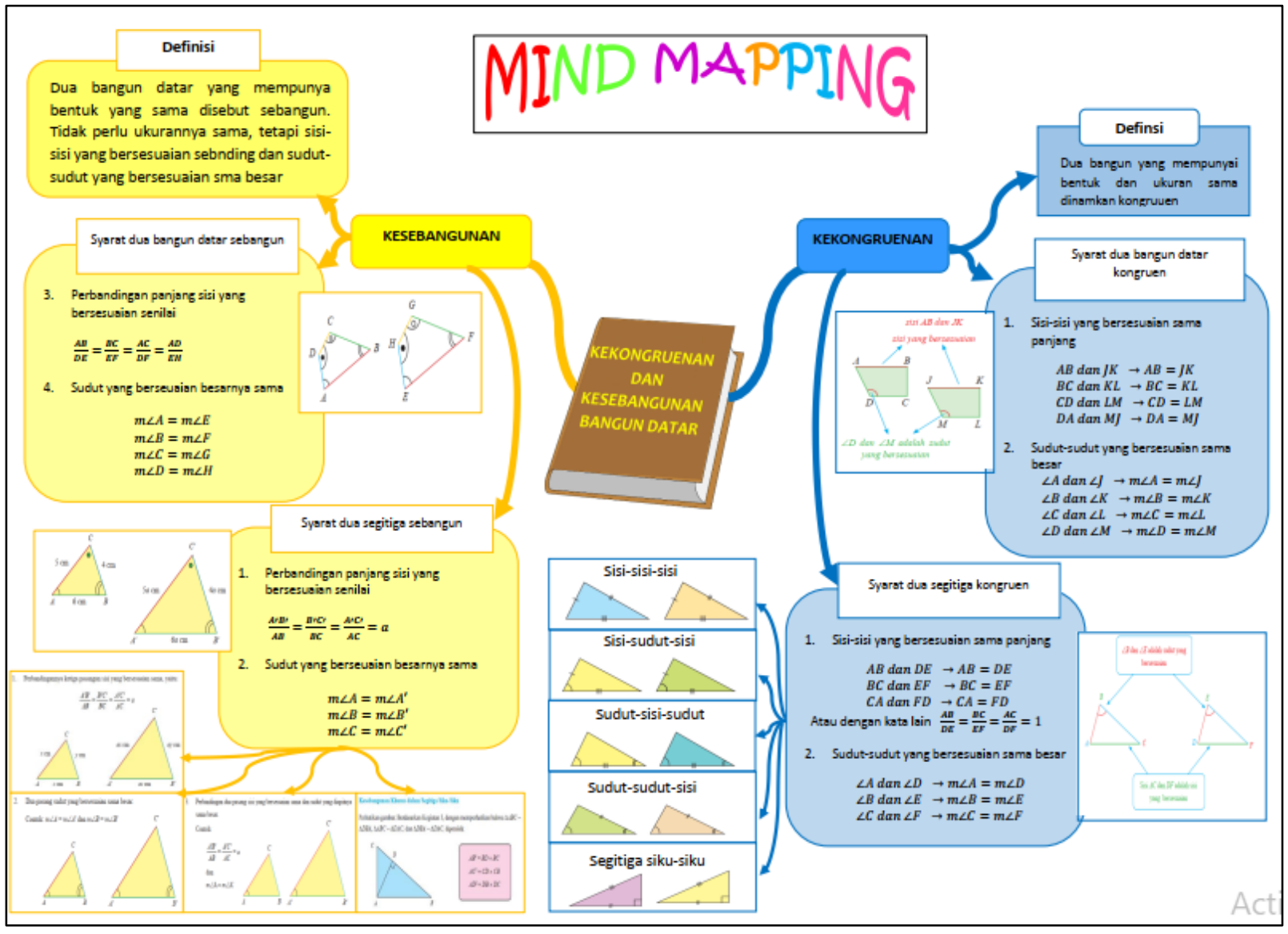

Gambar 4. Hasil Mind Mapping Materi Kekongruenan dan Kesebangunan

Gambar 4 menampilkan mind mapping dari materi kekongruenan dan kesebnagunan. Menerapakan mind mapping dalam kegiatan belajar mengajar bukanlah suatu hal yang mudah, hal ini dikarenakan diperlukan sebuah ketekunan dari pendidik dalam menyusun dan memikirkan pola rangkaian yang beragam sehingga bentuk penyajiannya tidak terkesan sama dan membosankan. Memikirkan pola rangkaian yang tepat dan menarik merupakan sebuah hal penting dalam pembuatan mind mapping sebab tidak hanya menjadi acuan guru dalam memberikan penjelasan materi dengan lebih baik lagi namun juga menjadi penolong peserta didik lebih mudah menyerap setiap poin penting materi. Dengan terus meningkatnya kreatifitas guru dalam pembuatan mind mapping memberikan peluang besar bagi peserta didik dan pendidik melaksanakan pembelajaran lebih efektif dan optimal. Pemilihan warna dan pengelompokan materi juga harus diperhatikan agar mind map yang dihasilkan mudah dipahami dan dilihat keterkaitannya melalui pengelompokan warna. Pada materi kekongruenan dan kesebangunan bangun datar peneliti memilih warna yang berbeda untuk mengelopokan sub-sub materi, pada skema sub materi kesebangunan terdapat dua warna yang mnunjukan bahwa bangun datar yang kongruen memiliki hubungan atau merupakan bagian dari kesebangun bangun datar dan masing- masing memiliki keistimewahan tersendiri yang membedakan kekongruenan dan kesebangunan bangun datar.

\subsection{Pembahasan}

Berdasarkan dari hasil penelitian, perancangan pembelajaran pada materi matematika Kelas IX semester ganjil dapat di jabarkan menjadi 4 bab yaitu, Bab 1 tentang Perpangkatan dan bentuk Akar, 
Bab 2 tentang Persamaan dan Fungsi Kuadrat, Bab 3 tentang Transformasi serta Bab 4 tentang Kekongurenan dan kesebangunan. Pendekatan mind mapping membutuhkan bahan-bahan seperti kertas putih polos dengan ukuran minimal A4, pensil warna atau spidol, imajinasi dan pemikiran kita sendiri. Dalam pembuatan mind mapping ada beberapa karakteristik pokok yang harus di penuhi. Karakteristik pokok yang dimaksud diantaranya adalah : kertas, warna, garis, huruf, kata kunci (key word), gambar (key image), dan struktur dalam sebuah mind mapping.

Ada beberapa hal yang harus di perhatikan sebelum membuat mind mapping peneliti yaitu kita harus menyiapkan terlebih dahulu bahan-bahan yang dibutuhkan, kemudian peneliti akan meringkas dan mengelompokan materi-materi atau sub-sub materi yang berkaitan, selanjutnya hasil ringkasan dari materi tersebut dituangkan kedalam bentuk mind mapping yang berupa gambar atau bagan sesuai kreativitas peneliti dengan mengikuti aturan atau langkah-langkah pembuatan mind mapping pada kajian teori. Dalam penelitian ini peneliti menggunakan warna yang berbeda-beda untuk setiap cabang dan sub-cabangnya, pemberian warna yang berbeda-beda bertujuan untuk melihat keterkaitan antar cabang dan sub-cabang. Dalam pembuatan mind mapping peneliti menggunakan Microsoft word dengan memanfaatkan shapes serta fitur-fitur lain yang terdapat pada microsof word, sehingga dapat diperolehlah mind mapping yang berdasar rangkaian mata pelajaran matematika untuk kelas IX semester ganjil yang terdiri dari 4 bab pelajaran yang dapat membantu guru dan siswa dalam proses pembelajaran dan materi pembelajaran dapat di tampilkan secara keseluruhan.

Hal ini sesuai dengan pendapat Swadarma bahwa mind mapping adalah cara mencatat yang efektif ,efesien, kreatif, menarik, mudah dan berdaya guna untuk mengembangkan ide dan pemikiran sesuai dengan kerja otak sehingga dapat membuka seluruh potensi dan kapasitas otak yang masih tersembunyi. Mencatat dengan mind mipping lebih menyenangkan karena siswa berkreasi dengan garis, gambar, warna dan segala hal yang ada dipikiran mereka [15].

Ada pun manfaat mind mapping yakni; (1) mampu mengumpulkan data yang hendak digunakan untuk berbagai keperluan secara sistematis, (2) memudahkan untuk melihat kembali sekaligus mengulang-ulang ide gagasan, (3) mampu menyeleksi informasi berdasarkan sesuatu yang dianggap penting dan sesuai dengan tujuan, (4) membuat banyak pilihan dari berbagai rute yang mungkin (5) mempercepat dan menambah pemahaman pada saat pembelajaran karena dapat melihat keterkaitan antar topik yang satu dengan yang lainnya, (6) mengasah kemampuan kerja otak karena mind mapping penuh dengan unsur kreatif.

Selain manfaat dari mind mapping, peneliti juga menemukan beberapa kesulitan dalam pembuatan mind mapping yaitu, dikarenakan adanya beberapa materi-materi yang cukup luas namun kertas yang digunakan oleh peneliti hanyalah kertas berukuran A4 sehingga ukuran gambar serta huruf yang digunakan dalam pembuatan mind mapping juga sangat kecil yang mengakibatkan sulit untuk dibaca. selain itu peneliti juga mengalami kesulitan dalam menggambar struktur mind mapping karena peneliti menggunakan aplikasi microsf word.

Untuk mengatasi beberapa kesulitan tersebut peneliti memberi solusi yaitu: dalam pembuatan mind mapping dengan materi yang cukup luas sebaiknya menggunakan kertas yang berukuran lebih besar dari A4 sehingga mind mapping yang dihasilkan akan lebih bagus, jelas dan menarik serta ukuran gambar dan huruf yang digunakan juga bias lebih besar dari ukuran yang digunakan pada kertas A 4 sehingga dapat dibaca dengan jelas dan mudah dipahami serta diingat. Dalam pembuatan mind mapping peneliti juga menyarankan menggunakan beberapa aplikasi lain selain Microsoft word dalam pembuatan mind mapping seperti XMind, SimpleMind, MindMeister, Coggle dan aplikasi lainnya yang bisa kita searching di google agar tampilan mind mapping yang kita peroleh lebih menarik. Selain itu, jika kita pandai menggambar, kita juga dapat menggambar sendiri dengan menggunakan pensil/bolpoint berwarna-warni sesuai dengan kreativitas kita sendiri.

\section{Kesimpulan}

Berdasarkan hasil penelitian dan pembahasan di atas dapat disimpulkan bahwa pembelajaran dengan penerapan mind mapping untuk mata pelajaran matematika kelas IX semester ganjil ini sangat efektif digunakan dalam proses pembelajaran. Mind mapping ini dibuat berdasarkan langkahlangkah yang telah ditentukan sebagai syarat dalam pembuatan mind mapping, sehingga 
menghasilkan sebuah mind mapping yang dapat membantu guru dan siswa dalam proses pembelajaran sehingga pelajaran matematika yang dilaksanakan selama satu semester ini (semester ganjil) menjadi lebih menyenangkan dikarenakan materi lebih mudah di pahami, di ingat,dan dipelajari serta membangkitkan daya minat belajar siswa yang mampu memicu semangat belajar sehingga peserta didik menjadi lebih aktif untuk menguasai materi yang di berikan dengan mudah.

Manfaat mind maping bagi siswa dalam proses pembelajaran yankni: (1) siswa dengan mudah dan cepat mengingat informasi, (2) siswa dengan mudah memperoleh ide penyelesaian masalah, (3) siswa dapat belajar dengan efektif dan efesien, (4) siswa dapat menigkatkan kemampuan kreatif, (5) materi pelajaran lebih mudah dan menarik untuk dibaca, (6) membantu siswa fokus berkonsentrasi terhadap materi yang di pelajari, (7) rantai keterhubungan antara pembahasan satu dengan pembahasan lainlebih mudah di pahami, sehingga pemahaman siswa akan lebi lama diingat, karena siswa memahami materi pelajaran bukan menghafalnya. Maanfaat mind mapping bagi guru yang menerapkannya yakni; (1) waktu persiapan mengajar jadi lebih sigkat, (2) revisi perbaikan mata pelajaran jadi lebih mudah, (3) materi pelajaran yang disampaikan terorganisir dengan baik, (4) menberikan inspirasi keatif bagi guru.

\section{Referensi}

[1] N. Epon, "Pengembangan Sumber Daya Manusia Bidang Pendidikan," Jurnal Pendidikan, No.1, Vol. 1, pp.1-9, 2018.

[2] K. Wenny, "Problematika Pembelajaran Matematika di Mts Swasta Al-Ittihadiyah Percut Sei Tuan," Skripsi, Program Studi Pendidikan Matematika, Fakultas Ilmu Tabiyah dan Keguruan, Universditas Islam Negeri Sumatra Utara Medan, 2018.

[3] S. Windura, Brain Management Series for Learning Strategy: Mind Map Langkah Demi Langkah cara Paling Mudah \& Benar Mengajarkan dan Membiasakan Anak menggunakan Mind Map untuk Meraih Prestasi. Jakarta: Gramedia, 2016.

[4] E. Carolin, Mind Mapping untuk Anak Sehat dan Cerdas, Yogyakarta: PT. Gramedia Pustaka Utama, 2009.

[5] D. Robbi And H. Mike, Quantum Learning: Membiasakan Belajar Nyaman dan Menyenangkan, Bandung: Kaifa Learning, 2013.

[6] B. P. A. Ida, "Pengembangan Peta Pikiran untuk Peningkatan Kecakapan Berpikir Kreatif Siswa," Jurnal Pendidikan dan Pengajaran Undiksa, vol.3, No.1, 2017.

[7] W. Tri, "Penerapan Metode Pembelajaran Mind Mapping untuk Meningkatkan Preatasi Belajar Matematika Peserta Didik Kelas V MI Baiturrohman Suwaloh Pakel Tulongagung Tahun Ajaran 2015/2016," Skripsi Jurusan Pendidikan Guru Madrasah Ibtadiah Fkultas Tarbyah dan Ilmu Keguruan Institut Agama Islam Negeri Tulungagung, 2016.

[8] M. H. Fuaddah, "Penerapan Model Pembelajaran Mind Mapping untuk Meningkatkan Penalaran dan Kreativitas Peserta Didik," Jurnal Indonesian Digital Jurnal of mathematics and Education, No.5, Vol. 9, 2019.

[9] N. F. Eka, and T. B. Mega, "Efektivitas Metode Pembelajaran Mind Mapping Pada Pembelajaran Matematika," Jurnal Ilmiah Pendidikan Matematika, No. 2, Vol. 8, pp. 371-377, 2019.

[10] M. Erma. "Penerapan Metode Mind Mapping untuk Meningkatkan Kemampuan Pemahaman Konsep Matematis Mahsiswa pada Materi Kalkulus I," Junal Prisma Universitas Suryakencana, No. 1, Vol. 6, pp. 17-31, 2017.

[11] A. Albi, And S. Johan, Penelitian Kualitatif. Sukabumi : CV Jejak, 2018.

[12] R. Ajat, Pendekatan Penelitian Kualitatif (Qualitatif Research Approach). Yogyakarta : Deepublish Publisher, 2018. 
[13] A. Stratus, And C. Juliet, Dasar-dasar Penelitian Kualitatif. Yogyakarta: Pustaka Pelajar, 2003.

[14] Sugiyono. Metode Penelitian Pendidikan. Bandung: Alfabeta, 2019.

[15] S. Doni, Penerapan Mind Mapping dalam Kurikulum Pembelajaran. Jakarta: Elex Media Komputindo, 2013. 